\title{
The Udmurt Ritual Year and Its Roots
}

\section{Mare Kõiva}

Estonian Literary Museum

Tatiana Vladykina, Galina Glukhova. Ar-god-bergan: Obryady i prazdniki udmurtskogo kalendarya. Izhevsk: UIIYaL UrO RAN, 2011, 319 p.

Year-Circle: Rituals and Celebrations of the Udmurt Calendar, by two renowned

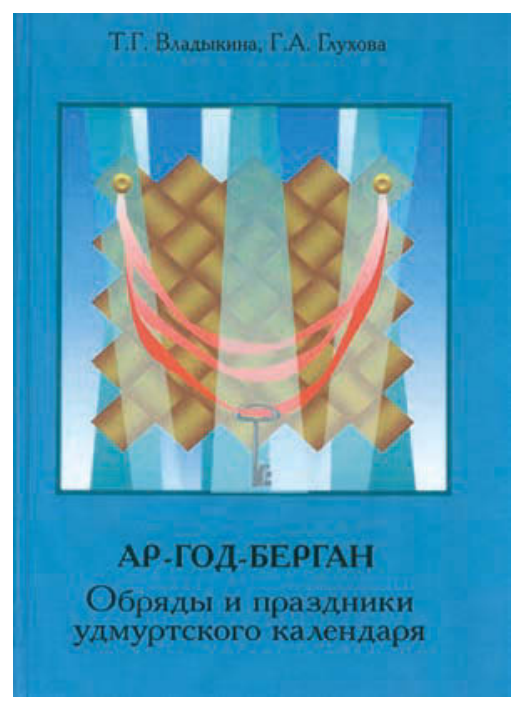
calendar specialists, Udmurt scholars, provides for the first time a complete overview of the system of ritual year customs with introductory articles, a glossary and sample texts. As befits an academic publication, indexes, a comprehensive list of sources and a bibliography are included. 
The literature even lists the BA and MA theses produced by students from various higher education institutions, as well as the publications by the Udmurt Research Centre for Udmurt History, Language and Literature. As for the references used in the book, there seems to be a comprehensive list of published studies on the Udmurt folklore and the Udmurt calendar.

Let us take a closer look at the content of this remarkable book. The authors present theoretical questions such as the possible beginning of year, suggesting it might be autumn because the terms autumn and year are similar; or spring because of its great importance as the beginning of the Udmurt calendar cycle. However, the main focus is on the beginning of the events and the celebrations of the ritual year.

The first part, an encyclopaedia-style glossary, introduces the nature of Udmurt holidays and related traditions. The glossary presents the Udmurt term, then its meaning, dialect forms and description. The sayings, formulae and Udmurt short incantations are listed, along with translations into Russian where needed. The holidays are followed by both a concise description of the main custom and cross-references to other related celebrations, which are included for a complete overview (St. George's Day - Akashka, Guzhdor).

As is typical for calendar customs, there are influences from the Christian calendar (especially in northern Udmurtia) alongside traditions from the neighbouring Turkic peoples (in southern Udmurtia), and holidays originating thousands of years ago. Holidays are spread over the four seasons and the twelve months, with a particularly high concentration from October to March; Easter and June stand out as well. The critical and festive month of October, the transition period at the end of the year, and the beginning of a new one, as well as the period around Easter, the autumn and winter season are therefore important. 
As the authors have also been involved in mythology studies for a long time, it is inevitable that links with mythology are highlighted in the introductory article as well as in the glossary. These include connections with the earth and sky, with water bodies and the forest, with gods, deities and the guardian spirits of the forces of nature. The reader can follow the categories of time and space and mythical concepts (the pillar of heaven, the stairway to heaven, among others). Attention has also been paid to the places of worship where rituals were held.

Vladykina and Glukhova emphasise the influence of nature on human activity, including the calendar system. They highlight gender roles in relation to holidays: men as the performers of animal sacrifices and as priests, women as ritual food preparers and participants. However, the system also includes women's holidays and the important role of women in the spring festivals, which are linked to fertility. Young people's celebrations are introduced, with a special focus on the celebrations of maidenhood, when young people from several villages gathered to have fun. The book does not overlook the celebrations at which children play an important role as performers of the games and as participants in the ritual. The role of older women as initiators and organisers of rituals is notable.

Ar-god-bergan is a rural calendar and therefore festive events, ritual foods and activities associated with the beginning and end of work in the fields are essential. The relationship between the living and the dead is and was an important element of community life.

The second part of the book, which presents sample texts in Udmurt on the core activities and terms found in the dictionary using sources from the $19^{\text {th }}$ century to the present day, is equally indispensable for researchers and people interested in culture. Translations into Russian have been added to each text and this greatly expands the range of users, offering an insight into universal phenomena, local feasts and unique celebrations and concepts. 
Mare Kõiva

Vladykina's and Glukhova's monograph covers community identity and economics, intertwining religious and secular, masking and mumming, entertainment and ritual foods, drawing attention to the cosmological roots of the ritual year. This multifaceted book surely needs a follow-up dictionary of mythology, book on Udmurt natural culture, or a book focusing on the key events in human life. 